\section{En vanskelig historie å forholde seg til}

Iversen $\mathrm{E}$.

\section{Skambitt}

Senvirkning og behandling av kvinner som har opplevd seksuelle overgrep. 125 s. Nestun: Folio forlag, 2010. Pris NOK 249 ISBN 978-82-92915-00-4

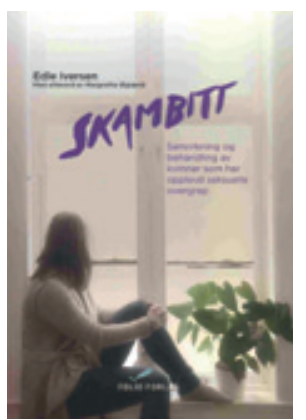

Dette er en liten selvbiografi. Under fullt navn og med stort mot skriver forfatteren, som nå er i fullt arbeid som lærer, om sitt eget liv som barn som blir seksuelt misbrukt av en nær person i familien. Hun

forteller også om hvordan livet hennes ble påvirket av hendelsene, og om hvordan hun veldig, veldig sakte kom seg ut av traumene og det som opplevelsene gjorde med henne, og videre i livet. Hun har fått sin egen terapeut til å skrive mer generelt om opplevelsen, behandling og senreaksjoner etter seksuelle misbruk.

Boken er nokså nøktern. Fortelleren beretter om et barn. Hun er ikke barn når hun skriver fortellingen, og fordi den er så rett på sak, kan man nesten glemme at dette har skjedd et barn, ikke en voksen kvinne som nå kan sette ord på det som har skjedd. Det kan nemlig virke lett, fordi hun faktisk greier det. Hun greier å fortelle om en litt dårlig kommuniserende, men hyggelig familie som ikke oppdaget overgrepene, og en liten, forknytt jente som bare fant seg i det og forble taus. Barn skal ikke oppleve slikt, men de gjør det. Og det setter varige spor. Jenta hadde alle mulige symptomer på at noe var galt, men fordi hun dels var taus og litt klovn, ble hun ikke fanget og fulgt opp. Hun bare levde, hver dag, med en stor angst og en stor skam. Hun var et lite barn, og overgrepene ble utført av en hun hadde tillit til, og de varte ved lenge. Hun hadde ikke noe valg da, og det er hun helt tydelig på. Det er først etterpå at hun har kunnet handle; fått overgriper dømt og fått tak i kreftene i seg selv.

Overgrepene ødela en barndom og fikk nesten tatt knekken på et helt liv. Det er de rå fakta man presenterer, både i selvbiografien og i den teoretiske delen. Men det finnes altså veier ut. Det er bare at det tar så utrolig lang tid. Sånn sett er dette også en viktig beretning om en grunnleggende terapeutisk prosess der terapeuten og pasienten kommer til mål sammen og kan dele prosessen med andre. Skribenten - klienten er beskjeden og bruker ikke mange ord, men hun viser hvor viktig det har vært å ha noen - her nær familie - å dele med, at det å anmelde overgrep ikke er noen lett sak, at det å vite at dette skjer med noen og ikke føle seg helt alene, kan sette i gang prosesser som fører frem, og at en samvandring med en terapeut over mange år faktisk kan bli et være eller ikke være for menneskeligheten $\mathrm{i}$ et menneskeliv.

Jeg syntes boken var utrolig ubehagelig å lese - fordi den blottstiller så mye. Samtidig er den modig, viktig og grensesprengende. De som driver med etterforskning av seksuelle overgrep, og med terapi av kvinner og menn som er utsatt for overgrep, vil sikker kjenne igjen noen faser og prosesser. For andre, som muligens ikke skjønner sammensurier av symptomer og psykiske lidelser hos pasienter, kan den kanskje åpne noen dører til forståelse og helbredelse.

Det er en svært konkret og viktig bok, til tross for at den ikke er noe litterært verk. Med sin knappe fortellerstil er den likevel kanskje nettopp det den bør være: en dør på gløtt inn til noe som bare er stort, mørkt og grusomt, men med et lite lysglimt av håp og optimisme. Terapeutens bidrag rammer det hele inn og gjør boken litt faglig profesjonell, slik at den også kan bli en bruksbok for behandlere. Det er utmerket, men historien står der likevel i all sin tørre grusomhet. For et mot som skal til for å dele den med oss.

\section{Johanne Sundby}

Institutt for allmenn- og samfunnsmedisin Universitetet i Oslo

\section{Usedvanlige metodeutfordringer}

Gjærum RG, red.

Usedvanlig kvalitativ forskning

Metodologiske utfordringer når informanter

har utviklingshemming. 270 s, ill. Oslo:

Universitetsforlaget, 2010. Pris NOK 349

ISBN 978-82-15-01615-3

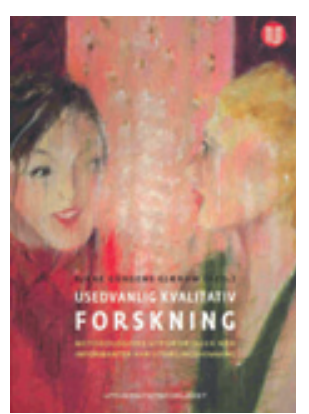

Antologien Usedvanlig kvalitativ forskning er redigert av Rikke Gürgens Gjærum. Den består av bidrag fra ni forfattere med samfunnsvitenskapelig og pedagogisk bakgrunn, og de fleste har tilknytning til Høg-

skolen i Harstad. Målgruppen er studenter på masternivå og forskere med interesse for kvalitativ forskning om hvordan det er å leve med utviklingshemning. Forfatterne gir ingen presis definisjon av hva de legger i begrepet «utviklingshemning». Tittelen signaliserer et perspektiv hvor man er mer interessert i å avdekke det usedvanlige enn å ordne virkeligheten med basis i diagnostiske kategorier. I det innledende kapitlet peker Karl Elling Ellingsen og redaktøren på behovet for mer kunnskap om hvilke erfaringer personer med utviklingshemning har med eget liv og møtet med hjelpeapparatet.

Den første delen omhandler teoretiske perspektiver, og den andre delen består av såkalte «pragmatiske metodereiser». Bidragsyterne peker bl.a. på særskilte etiske spørsmål innen kvalitativ forskning om utviklingshemning, utfordringer knyttet til å intervjue personer med redusert kognitiv funksjon, og nytten av å kombinere ulike metoder for datainnsamling. Flere av tekstene har en refererende stil, og en del kapitler kunne ha vært tydeligere avgrenset. Et kapittel om bruk av fokusgrupper inneholder eksempelvis en redegjørelse for generelle prosedyrer for transkripsjon og fortolkning av data. Når man leser hele boken, blir det en del gjentakelser, særlig av teoretiske referanser og perspektiv. Det er en del interessante eksempler, men forfatterne kunne i enda større grad ha forankret kapitlene i egen forskning, hvor de gjorde rede for aktuelle forskningsspørsmål, gruppen man studerte, hvordan man planla datainnsamling, og hvordan man håndterte utfordringer man møtte underveis.

\section{Jan C. Frich}

Avdeling for helseledelse og helseøkonomi Universitetet i Oslo

\section{Uklart om viktig emne}

\author{
Pettersen K-S, Simonsen E. \\ Anerkjennelse og profesjon \\ 76 s, tab, ill. Oslo: Cappelen Damm, 2010. \\ Pris NOK 248 \\ ISBN 978-82-02-30617-5
}

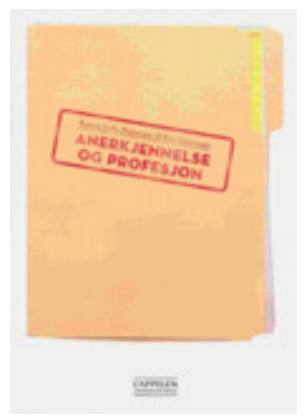

Til tross for den noe intetsigende tittelen takket jeg med glede ja til å vurdere denne boken, fordi jeg mener anerkjennelse i for liten grad kommer til uttrykk både $\mathrm{i}$ forholdet mellom leger og pasienter, leger og andre helsearbeidere og leger seg imellom. Forfatterne er henholdsvis seniorforsker ved Arbeidsforskningsinstituttet i Oslo og professor ved Institutt for spesialpedagogikk ved Universitetet i Oslo. De burde ha gode forutsetninger etter mange års erfaring fra eget profesjonsutøvende arbeid og undervisning. Forfatterne skriver at formålet er å vise ulike forståelser av hva 